\title{
Evaluation of formation and reparcelling of land parcel projects
}

Vaiva Stravinskiene்,

\section{Giedrius Balevičius}

Aleksandras Stulginskis University, Studentu 11, LT-53361 Akademija, Kaunas Distr., Lithuania

E-mail:vaiva.stravinskiene@asu.lt; gbalevicius@gmail.com
The article presents an analysis of two subjects: the motives of formation and reparcelling of land parcel projects and evaluation of their solution effects on landscape, and rationality and compatibility of projected land use.

The main intentions of the projects were estimated after the research. The first intention is to divide land parcels according to parts belonging to co-owners (to form separate parcels). The second intention is to divide land parcels in order to sell or grant to other persons. The third intention is to specify borders between owned and neighbouring parcels.

An analysis of ecological balance rate indicators of project solutions shows a result that a scarcely stable territory was in 8 parcels $\left(K_{e s}=0.34-0.50\right)$, a totally ecological unstable territory was in 13 parcels $\left(K_{e s} \leq 0.33\right)$, and a moderately stable territory was only in 2 parcels. It was noticed that in many cases there were small negative changes of the ecological balance rate. It depends on the dividing process of arable land and more ecologically stable territories.

Key words: ecological balance, land use rationality, reparcelling

\section{INTRODUCTION}

Land must be rationally planned in order to use it. By using the properly planned land you must ensure to keep the required production level of agriculture, soil protection, ecological stability of terrain, and agricultural land use improvement.

Land use planning is a system of tools, used by the Government to implement land property and its usage section politics: applying terrain planning tools to organize consumption of land fund, that is valid academically, rational and favourable for environment, and that does accounting of country's land fund, forms land parcels, measures boundaries of administrative units, attaches land to agriculture activity territories and other sections of utilitarian environmental management (Tarvydiené, 2008).

The order of rational agricultural landholding depends on the law, Government's decrees, and other decrees that regulate documents of terrain planning. They define the principal specific purpose of land use of a particular territorial segment, the method and nature of the use of a land parcel, and other conditions and regulations (Kavaliauskienè, 2008).

Rational agricultural land-holding is planned by land use planning and other projects. Various farm holding branches that require land use are adjusted by these projects. Furthermore, there must be considered natural resources saving subject and other interests of society requirements.

Formation and reparcelling of land parcel projects are being prepared and implemented when it is needed to divide, partition, merge or amalgamate land parcels that are registered in the Immovable Property Register. This common land use service is used by land owners who want to regulate land, which is recovered from the agrarian reform or acquired by other means. According to the Planning Department's survey, formation and reparcelling of land parcels projects were arranged 1-1.5 k times in rural area yearly (Aleknavičius, Liaskovskaja, 2009).

In projects of land parcel formation and reparcelling the principal specific purpose of land use, the method and nature of the use of a land parcel must be defined. It is regulated by the Government's 
decree and rules ratified by the Ministers of the Departments of Environment and Agriculture (Lietuvos..., 2004). Other Government's decree is used when it is needed to identify or eliminate land easements (Žemès servitutų..., 2004).

Land parcels must be formed properly in order to use them rationally and to avoid deterioration of ecological, recreational conditions and possibilities to develop agricultural activity. While separating solid arable land, meadow and forest parcels, land parcels must be formed compactly, in a rectangular or similar form and suited rationally (Žemès sklypu..., 2004). But in the current law there is no requirement for the minimum size and the form of the agriculture parcel, for example: the width of the parcel (Aleknavičius, 2012). Results of the research demonstrate that a key indicator in the human system (i. e. the parcel size and changes in the parcel size), which is driven by socioeconomic processes as well as policy, has direct implications for indicators in the natural system (Robinson, 2012). Land-use convenience, time and labor costs allocated to economic activities, good-neighbourly relations highly depend on the use of land use boundary configuration (Sližienè, 2010).

The aim of this article is to analyze the motives of formation and reparcelling of land parcels projects, evaluate their solutions' effects on landscape and rationality, compatibility of projected land use.

\section{METHODOLOGY OF RESEARCH}

In order to do research, there were analyzed 331 projects for formation and reparcelling of land parcels, they were created in eastern Lithuania from 2005 to 2010 . There were 2 parameters to evaluate projects during the analysis: project solution effects on environment and landscape; rationality and compatibility of projected land use.

The ecological balance rate is counted according to the following formula:

$$
K_{e s}=\sum k_{e} \times P / \sum P,
$$

where $K_{e s}$ is the ecological balance rate, $k_{e}$ is the land type ecological balance rate, $P$ is the land type estate (area).

The measured land ecological balance rate is given in Table 1.
Table 1. Ecological balance rate (Aleknavičius, 2008)

\begin{tabular}{|c|c|}
\hline Land & $\begin{array}{c}\text { Ecological balance } \\
\text { rate } K_{e s}\end{array}$ \\
\hline Arable lands & 0.14 \\
\hline Meadows & 0.62 \\
\hline Pastures & 0.68 \\
\hline Gardens & 0.43 \\
\hline Forests & 1.0 \\
\hline Flora of trees and bushes & 0.4 \\
\hline Marshes & 0.79 \\
\hline Water basins & 0.79 \\
\hline Closed territories, roads & 0.0 \\
\hline Impaired lands (quarries) & 0.0 \\
\hline Other lands & 0.68 \\
\hline
\end{tabular}

When the ecological balance rate $\left(K_{e s}\right)$ average value is 0.67 or more, the territory is balanced ecologically, when it is $0.51-0.66$, the territory is stable moderately, when this value is $0.34-0.50$, the territory is scarcely stable, and if $K_{e s}$ is less than 0.34 , the territory is unstable. To form a land parcel of arable land or sowed meadows, its length and width proportion must be 1:3 or less. Land parcel boundaries must be identified with natural contours or artificial objects. If there are not any natural or artificial objects, land parcel boundaries must be projected straight to compose regular boundaries of an arable land parcel.

There were used cartographical, logical and analytical thinking methods.

\section{RESULTS}

While forming a real estate object, partitioning or dividing it, newly formed real estate objects must meet these requirements:

1) The used method must not contradict with documents of terrain planning;

2) The principal specific purpose of land use and the nature of farm holding use must not contradict with documents of terrain planning;

3) These objects can function independently from each other unless law defines otherwise;

4) Possibility to estimate and calculate each object's value (Žemès sklypų..., 2004).

Land parcels can be formed to prepare not only land use planning projects, but also detailed plans that implement terms of land administration:

1) A land parcel with buildings on it can be divided or partitioned only in a way to be able to 
exploit the building in a single parcel. Several land parcels cannot be formed under one registered building;

2) Formative land parcel boundaries between corner points must compose a closed contour. Several land parcels divided by other real estate objects (roads, streets, railroads, unprivatized objects, etc.) must be formed as separate land parcels;

3 ) If there are not any possibilities to partition a land parcel into parts indicated by co-owners, formative parcel area must be rounded up, but the whole land parcel's area must not be changed. In the case when the area of a land parcel is calculated in hectares, the rounded value is 2 numbers after comma;

4) While modifying land parcel boundaries and size, forming new land parcels, it is a must to follow defined requirements of rational use of land, detail plans and land use planning project preparation.

There were analyzed 331 projects for formation and reparcelling of land parcels created from 2005 to 2010 and owned by 455 possessors. The most usual operation is parcel dividing (218 cases, $66.9 \%$ ) - present parcels are divided into 2 or 3 land parcels (Table 2).

The majority of projects, i. e. 74, were developed in 2007 during the economic boom and more intense selling of land parcels. For this reason the parcels were divided into smaller ones. 55 projects

Table 2. Reasons of formation and reparcelling of land parcels

\begin{tabular}{|c|c|c|c|c|c|c|}
\hline \multirow[b]{2}{*}{ 己゙્ } & \multirow[b]{2}{*}{ 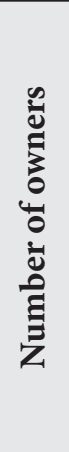 } & \multirow[b]{2}{*}{ 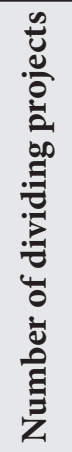 } & \multicolumn{4}{|c|}{ Reasons of land parcel dividing } \\
\hline & & & 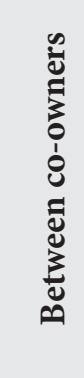 & 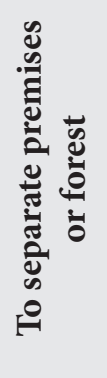 & 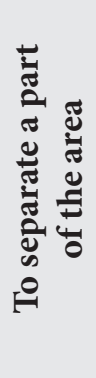 & 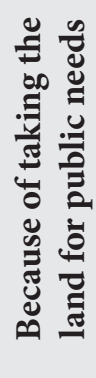 \\
\hline 2005 & 67 & 39 & 13 & 6 & 18 & 2 \\
\hline 2006 & 70 & 54 & 17 & 1 & 33 & 3 \\
\hline 2007 & 98 & 74 & 8 & 10 & 55 & 1 \\
\hline 2008 & 88 & 64 & 12 & 8 & 44 & - \\
\hline 2009 & 96 & 72 & 16 & 9 & 47 & - \\
\hline 2010 & 36 & 28 & 5 & 2 & 21 & - \\
\hline Total: & 455 & 331 & 71 & 36 & 218 & 6 \\
\hline
\end{tabular}

separating a part of the area were compiled (it equals to almost $17 \%$ of all projects analysed).

One can make an assumption that owners of land parcels when pursuing projects of land parcel separation do not take into consideration the criteria of parcel rationality, ecological balance, etc. The main aim is protection of ownership, which, having separated a part of a land parcel, allows one to dispose of his / her property irrespective of co-owners. In addition, the tendency of land parcels analysed was observed - the area of separated land parcels is at least 50 ares. Under the guidance of Rural Development project preparation schemes of selecting a location for a farmstead can be designed within a parcel no smaller than 50 ares.

The main reasons to prepare the projects of land parcel formation and rearrangement are as follows:

1) To partition land parcels according to parts belonging to co-owners (to form separate parcels);

2) To divide land parcels in order to sell or grant to other person;

3) Using the land parcel for a farmstead (especially in the suburbs).

While reparcelling agricultural land, it is important that after reparcelling there would be better conditions to use land according to its defined purpose. That is why instructions are the same as to form new land parcels during the reform. Furthermore, it must be estimated if private interests to divide land parcels do not contradict with the purpose to make better conditions for land use (arable land cultivation or other agricultural activity).

During the analysis of the prepared projects, it was estimated what size and form composed the arable land and how much they are rational from a standpoint of mechanical land cultivation.

Land parcels must be formed properly to use them rationally and to avoid deterioration of ecological, recreational conditions; possibilities to develop agricultural activity; activity conditions for nearby land parcels' users (Aleknavičius, 2001; Lankelis, 2002). As we can see in Fig. 2, there is a road projected beside the parcels. After forming the dividing project parcels remain compact and each of them has road access (Figs. 1, 2).

Many parcels before dividing and reparcelling projects were formed like trapeziums (37.12\%). 


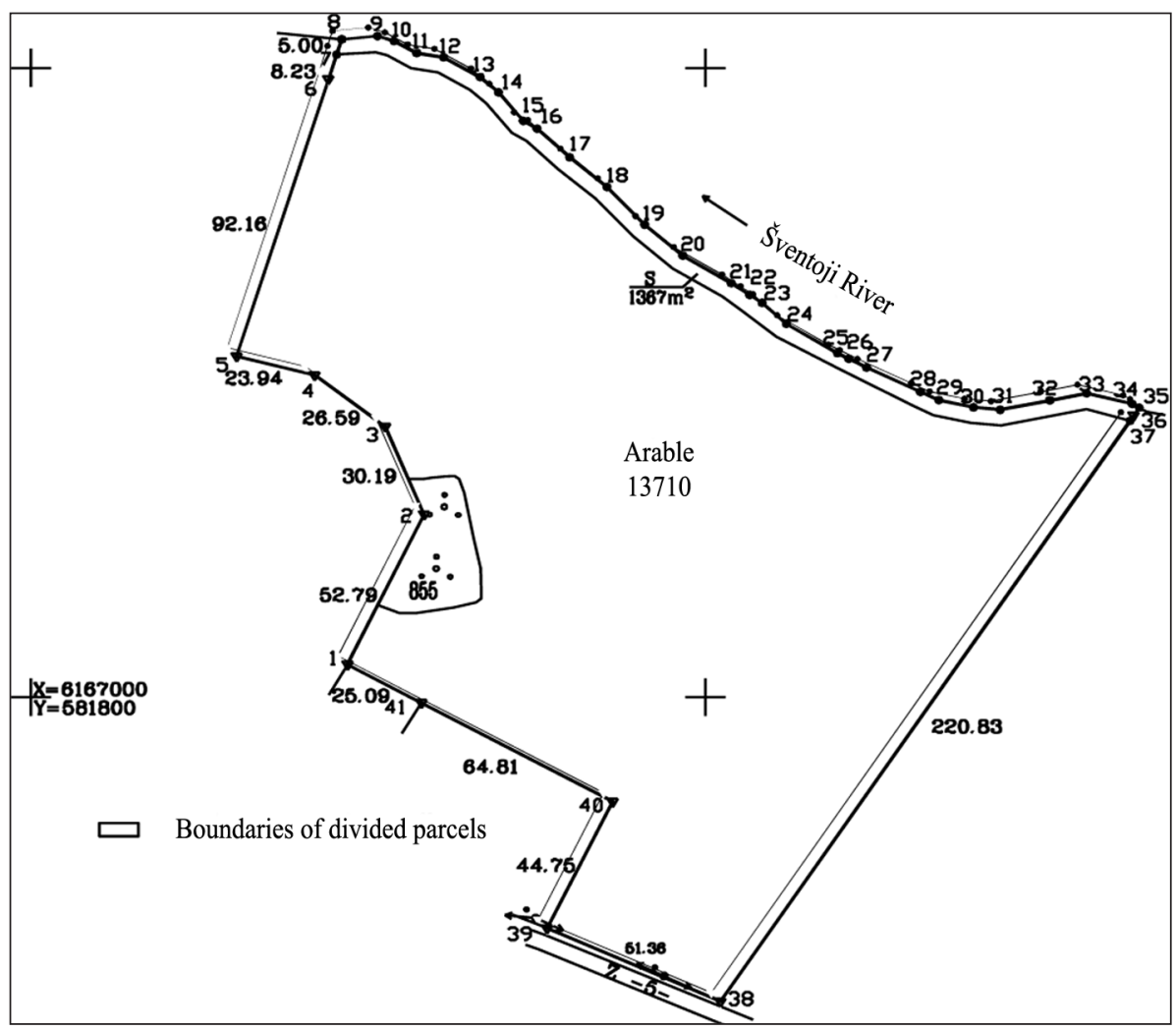

Fig. 1. The land parcel owned by $\mathrm{N}$ possessors before the dividing and reparcelling project

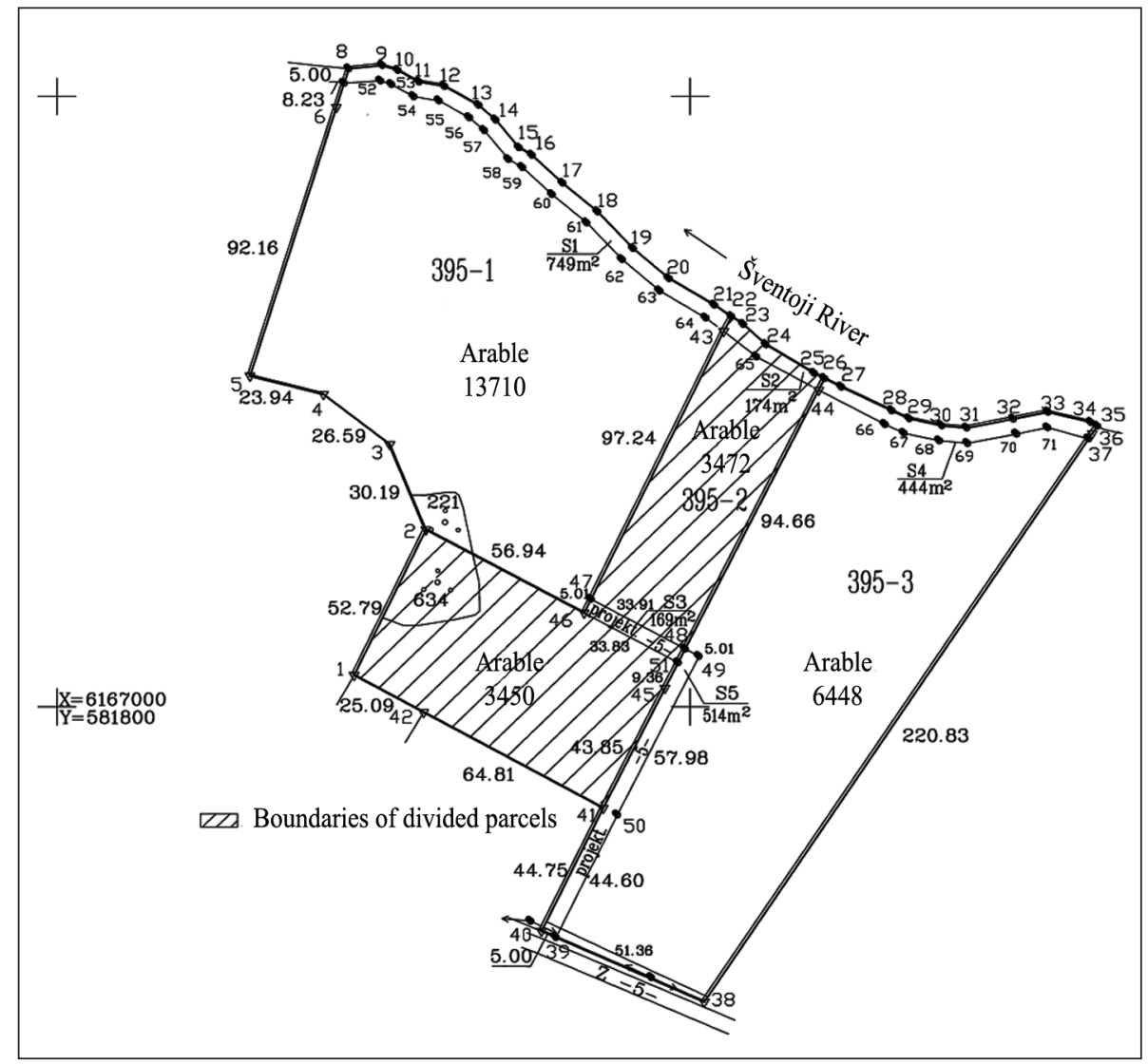

Fig. 2. The dividing and reparcelling project of the land parcel owned by $\mathrm{N}$ possessors 
After dividing and reparcelling projects, the number of regular parcels increased considerably (73.17\%) (Fig. 3).

To sum up, it can be said that quality of parcels improved in terms of configuration but there are still many irregular form parcels. There are various reasons why irregular form parcels occur after forming and reparcelling projects. Usually these kinds of parcels are formed beside lakes, every parcel owner on request wants to have access to the shore of a lake.

It is usual that residential or other constructional land parcels are formed from agricultural land which has a polygonal or patch form (Ramanauskas, Dringelis, 2011). An example of an incompact parcel is shown in Fig. 4.

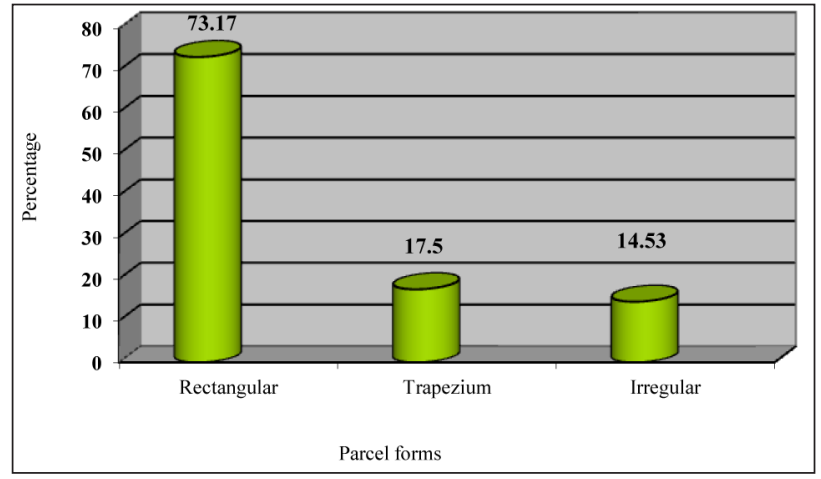

Fig. 3. The number of land parcels in terms of their forms after formation and reparcelling projects
The parcel project is implemented under owner's request and it is an example of an incompact parcel dividing and reparcelling project. This kind of projects usually occurs in "prestigious" places because citizens request access to the lake or, like in this instance, a pond that is requested to have by a 7-1 parcel owner.

In the next example (Fig. 5), there are forming narrow land parcels that contravene the recommendable length and width and cannot ensure rational land use.

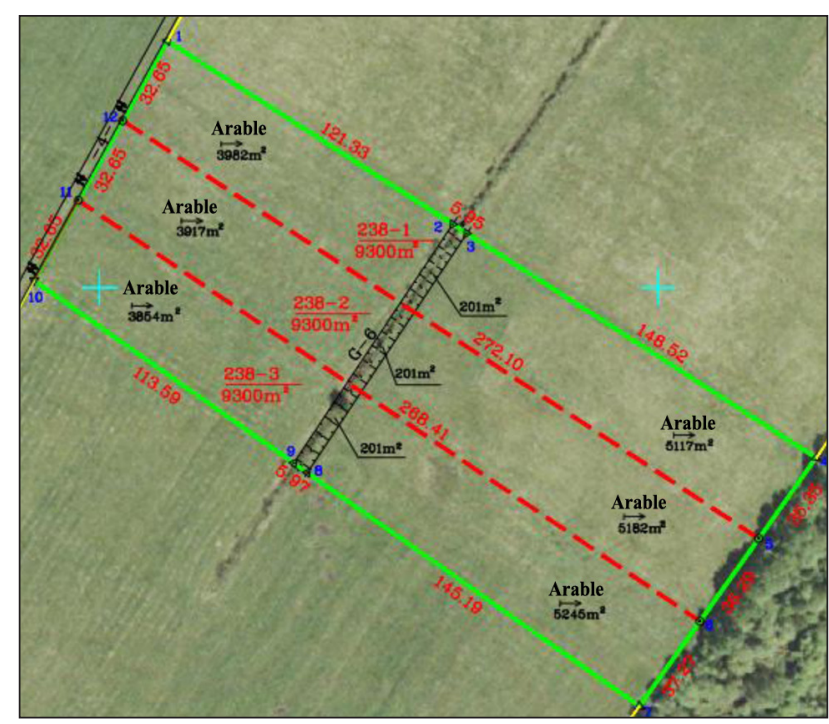

Fig. 5. Land parcel, owned by $\mathrm{N}$ possessor, being divided

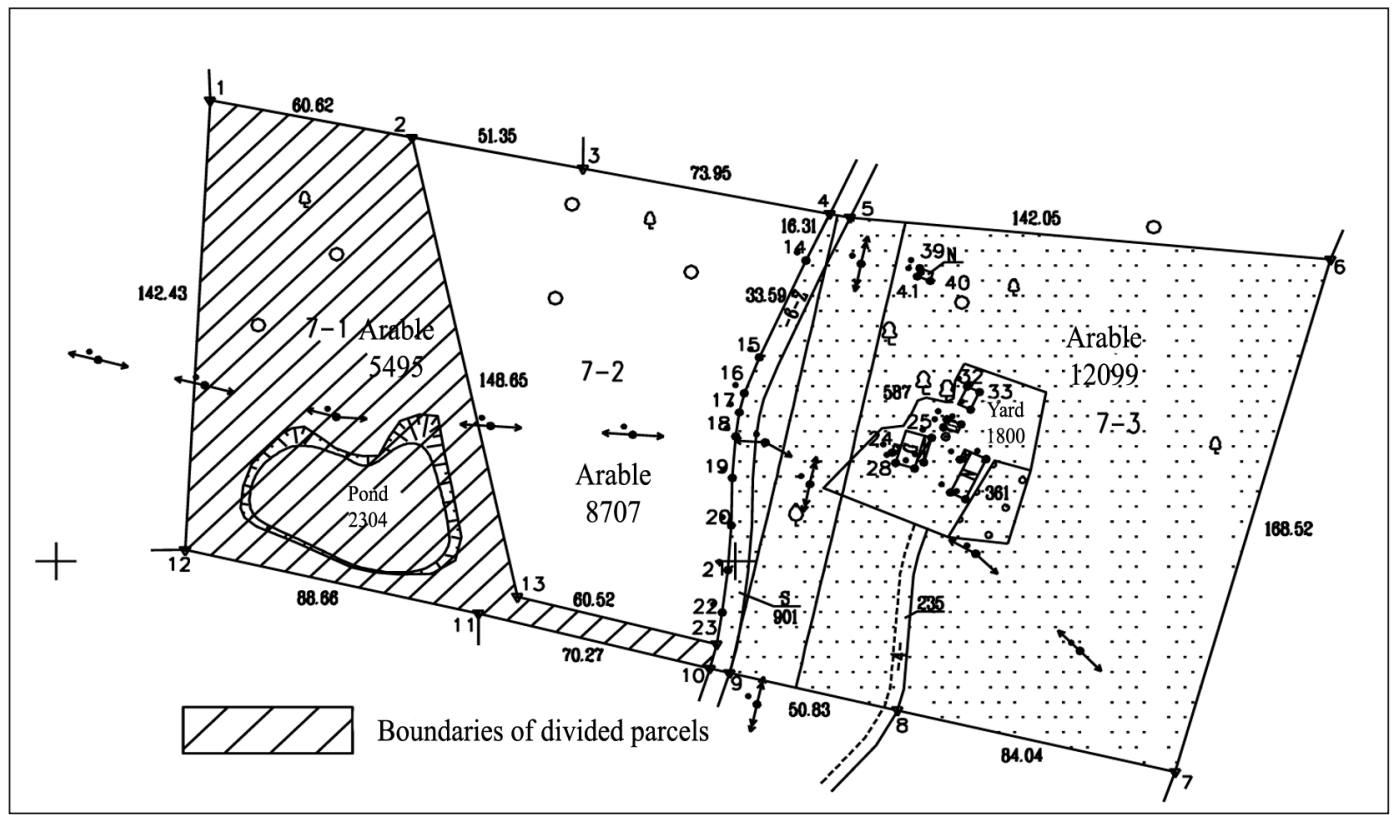

Fig. 4. The dividing and reparcelling project of the land parcel owned by $\mathrm{N}$ possessors 
General requirements of instructions cannot provide sufficiency for the projector to the object against land owner's requests, which usually deteriorate conditions. It is like that because there are no particular standards in project preparing instructions. During the analysis, there were noticed several cases when agricultural purpose parcels were 1) divided into a narrow strip or even zigzag; 2) partitioned into several small parcels for premises; 3) parcel corners were composed into various geometrical forms even in reclaimed lands, flat relief. Eventually that burdens mechanical cultivation (Aleknavičius, Liaskovskaja, 2009).

Agricultural territory land use planning is secure when projected means meet requirements of landscape forming. In order to optimize landscape, it is a must to analyze its state - natural and semi-natural sprouting places and their functions; also it is needed to calculate the ecological balance of a particular territory (Sudoniené, 2003).

There were made calculations of the ecological balance for some parcels on purpose to estimate the partitioned land parcels' effect on the landscape. Evaluated parcels were those, which were partitioned into three separate parcels and which ecological balance before reparcelling was unstable, scarcely stable or moderately stable. Project solution ecological balance rate indicators were analyzed. As a result, it was estimated that a scarcely stable territory was in 8 parcels $\left(K_{e s}=0.34-0.50\right)$, a totally ecological unstable territory was in 13 parcels $\left(K_{e s} \leq 0.33\right)$, a moderately stable territory was only in 2 parcels (Table 3).

Summarizing the estimated ecological balance rate indicators, it was noticed that after reparcelling of an initial parcel into more parcels, in many cases this indicator does not change considerably, yet it increases. In separate occasions ecological balance decreases (17.4\% of the 23 parcels analysed). It is determined by arable land partition from ecological stable territories. Therefore, while partitioning land parcels land separation should be mosaic or a part of the projected territory should be transformed into more ecologically stable one to ensure natural variety.
Table 3. Change of ecological balance rate

\begin{tabular}{|c|c|c|c|}
\hline \multirow{2}{*}{$\begin{array}{l}\text { Ecological balance } \\
\text { rate before } \\
\text { reparcelling }\end{array}$} & \multicolumn{3}{|c|}{$\begin{array}{c}\text { Ecological balance rate after } \\
\text { reparcelling }\end{array}$} \\
\hline & $\begin{array}{c}1 \\
\text { parcel }\end{array}$ & $\begin{array}{c}2 \\
\text { parcels }\end{array}$ & $\begin{array}{c}3 \\
\text { parcels }\end{array}$ \\
\hline 0.32 & 0.43 & 0.43 & 0.20 \\
\hline 0.14 & 0.14 & 0.32 & 0.32 \\
\hline 0.17 & 0.14 & 0.21 & 0.52 \\
\hline 0.15 & 0.15 & 0.15 & 0.15 \\
\hline 0.48 & 0.45 & 0.30 & 0.45 \\
\hline 0.20 & 0.20 & 0.20 & 0.20 \\
\hline 0.45 & 0.50 & 0.50 & 0.35 \\
\hline 0.40 & 0.43 & 0.43 & 0.35 \\
\hline 0.13 & 0.13 & 0.13 & 0.13 \\
\hline 0.29 & 0.25 & 0.30 & 0.45 \\
\hline 0.45 & 0.35 & 0.45 & 0.48 \\
\hline 0.30 & 0.40 & 0.45 & 0.40 \\
\hline 0.35 & 0.30 & 0.30 & 0.40 \\
\hline 0.60 & 0.55 & 0.60 & 0.66 \\
\hline 0.50 & 0.50 & 0.45 & 0.30 \\
\hline 0.25 & 0.30 & 0.30 & 0.25 \\
\hline 0.25 & 0.25 & 0.25 & 0.15 \\
\hline 0.20 & 0.20 & 0.15 & 0.15 \\
\hline 0.45 & 0.40 & 0.50 & 0.50 \\
\hline 0.65 & 0.50 & 0.50 & 0.60 \\
\hline 0.34 & 0.42 & 0.45 & 0.30 \\
\hline 0.15 & 0.15 & 0.15 & 0.20 \\
\hline 0.13 & 0.13 & 0.13 & 0.13 \\
\hline
\end{tabular}

\section{CONCLUSIONS}

1. Having analysed the data of project solution ecological balance coefficient indicators of the parcels, which were subdivided into three parcels and the ecological balance of which before the rearrangement was low or average low, it was obtained that a scarcely stable territory was in 8 parcels $\left(K_{e s}=0.34-0.50\right)$, a totally ecological unstable territory was in 13 parcels $\left(K_{e s} \leq 0.33\right)$, and a moderately stable territory was only in 2 parcels.

2. Many small changes of the estimated ecological balance rate indicators were noticed after land parcel dividing. They depend on the dividing process of arable land and more ecologically stable territories.

3. During the partitioning of land parcels, land separation should be mosaic or a part of projected territory should be transformed into more 
ecologically stable one to ensure natural variety. In order to make projects of formation and reparcelling of a land parcel, it is important to evaluate both land use rationality and ecological stability.

Received 15 May 2013

Accepted 12 May 2014

\section{REFERENCES}

1. Aleknavičius A. 2001. Ūkių žemėnaudų pertvarkymo ekonominiai tyrimai. Vandens ūkio inžinerija: mokslo darbai. Nr. 15(37). P. 3-7.

2. Aleknavičius P., Liaskovskaja J. 2009. Žemètvarkos planavimo dokumentų reikšmè kaimo ekonominei ir socialinei plètrai. Darnaus vystymo strategija ir praktika: mokslo darbai. M. Romerio universitetas. Nr. 1(3). P. 55-67.

3. Aleknavičius P. 2012. Nepriklausomoje Lietuvoje atliktų žemés ūkio paskirties žemès pertvarkymo darbų palyginamoji analizè. Viešoji politika ir administravimas. T. 11. Nr. 2. P. 246-259.

4. Aleknavičius P. 2008. Žemes tvarkymo reglamentavimas: mokomoji knyga. Kaunas: Ardiva, $179 \mathrm{p}$.

5. Gurskienė V., Makauskas J. 2002. Ūkininkavimo sąlygu analizè Vidurio Lietuvoje. Vandens ūkio inžinerija: mokslo darbai. T. 18. Nr. 40. P. 101-107.

6. Kavaliauskiene B. 2008. Žemètvarkos projektavimas: mokomoji knyga. Kaunas: Ardiva. 31 p.

7. Lankelis L. 2002. Žemès sklypo dydžio ir konfigūracijos įtaka racionaliam ūkių žemènaudų formavimui. Vandens ūkio inžinerija: mokslo darbai. T. 18. Nr. 40. P. 65-70.

8. Lietuvos Respublikos Vyriausybès nutarimas 2004-10-13 Nr. 1278 „Dèl pagrindinès tikslinès žemès naudojimo paskirties nustatymo ir prašymu leisti pakeisti pagrindinę tikslinę žemès naudojimo paskirti padavimo, nagrinejjimo ir sprendimuc prièmimo tvarkos patvirtinimo“. Valstybès žinios. 2004. No. 152-5575.

9. Ramanauskas E., Dringelis L. 2011. Žemès sklypų pertvarkymo patyrimas planuojant miestų teritorijas. Urbanistika ir architektūra. Nr. 35(4). P. 285294.

10. Robinson D. T. 2012. Land-cover fragmentation and configuration of ownership parcels in an exurban landscape. Urban Ecosystems. Vol. 15. P. 5369.

11. Platonova D., Setkovska L., Jankava A. 2011. Assessment Principles of Land Fragmentation. Baltic Surveying'11: Proceedings of the International Scientific Conference. Jelgava. P. 117-124.

12. Sliziene G. 2010. Ribų ištiesinimas - žemès naudojimo optimizacija. Matavimu inžinerija ir GIS. Mastaičiai. P. 55-59.
13. Sudonienè V. 2003. Žemès ūkio paskirties teritoriju tvarkymo pagrindimas: daktaro disertacija. LŽŨU. $140 \mathrm{p}$.

14. Tarvydienè M. E. 2008. Žemètvarkos pagrindai: mokomoji knyga. Kaunas: Ardiva. 175 p.

15. Žemès servitutu nustatymo administraciniu aktu taisyklès. 2004. Valstybès žinios. Nr. 153-5579; 2010. Nr. 107-5518.

16. Žemès sklypų formavimo ir pertvarkymo projektų rengimo ir igyvendinimo taisyklès. 2004. Valstybès žinios. Nr. 149-5420; 2007. Nr. 63-2430; 2009. Nr. 50-2020.

\section{Vaiva Stravinskienė, Giedrius Balevičius}

\section{ŽEMĖS SKLYPŲ FORMAVIMO-PERTVARKYMO PROJEKTU VERTINIMAS}

Santrauka

Straipsnyje analizuojami žemès sklypų formavimo-pertvarkymo projektų rengimo motyvai, ịvertintas projektų sprendinių poveikis kraštovaizdžiui ir suprojektuotų žemėnaudų racionalumas bei kompaktiškumas. Atlikus tyrimą nustatytos pagrindinès projektų rengimo priežastys: žemès sklypai atidalinti pagal bendraturčiams priklausančias dalis (suformuoti atskiri sklypai); žemès sklypai padalinti siekiant juos parduoti ar dovanoti kitiems asmenims; patikslintos sklypų ribos tarp kaimyninių žemės savininkų. Išanalizavus projektinių sprendinių ekologinio stabilumo koeficiento rodiklių duomenis, gauta, kad mažai stabili teritorija buvo 8 sklypuose $\left(K_{e s}=0,34-0,50\right)$, visiškai ekologiškai nestabili 13 sklypu $\left(K_{e s} \leq 0,33\right)$, vidutiniškai stabili - tik dviejuose sklypuose. Dažniausiai stebèti nedideli neigiami pokyčiai, kuriuos lemia ariamosios žemès atskyrimas nuo ekologiškai stabilesnių teritorijų.

Raktažodžiai: ekologinis stabilumas, žemėnaudų racionalumas, sklypų pertvarkymas 